\title{
Microbial Degradation of Petroleum Hydrocarbon
}

\author{
Forkan Ahamed, M Hasibullah, Jannatul Ferdouse and M Nural Anwar \\ Department of Microbiology, University of Chittagong, Chittagong-4331, Bangladesh.
}

(Received 05 January 2010; Accepted 23 July 2010)

\begin{abstract}
The present research was undertaken to isolate and characterize petroleum hydrocarbon degrading microbes from ship-breaking yards at Vatiary and Kumira coast in Chittagong. Twenty different petroleum hydrocarbon contaminated composite samples were collected and the total bacterial count was found to vary between $2.7 \times 10^{3} \mathrm{cfu} / \mathrm{gm}$ and $1.77 \times 10^{7} \mathrm{cfu} / \mathrm{gm}$. Ten isolates were finally selected through secondary screening by Bushnell-Hass mineral salt medium using kerosene, diesel and engine oil as carbon source. They were provisionally identified and found closely related to the species Listeria monocytogenes, Staphylococcus aureus, Pseudomonas alcaligenes, Listeria grayi, Bacillus pasteurii, Bacillus badius, Bacillus cirroflagellosus, Bacillus circulans, Bacillus brevis and Citrobacter freundii. Greasy spot test was used as the primary indicator of microbial degradation of kerosene, diesel and engine oil. A more specific experiment was carried out to estimate the rate of degradation by the isolates. The highest $(\mathbf{9 6 . 8} \%)$ degradation of diesel was shown by $B$. brevis, followed by $\mathbf{9 2 \%}, \mathbf{8 8 . 8} \%$ and $\mathbf{8 4 . 8} \%$ of diesel degradation by the strains of $P$. alcaligenes, $B$. cirroflagellosus and $C$. freundii, respectively. The highest degradation of kerosene $(78.26 \%)$ and engine oil $(43.97 \%)$ by $S$. aureus and $L$. monocytogenes respectively, were also observed.
\end{abstract}

Keywords: Microbes, Petroleum hydrocarbon, Degradation

\section{Introduction}

The unprecedented population increase and industrial development during the twentieth century not only increased conventional solid and liquid waste pollutants to critical levels but also produced a range of previously unknown pollution for which the society was unprepared. Petroleum hydrocarbons although are not xenobiotic, by their large scale use and accidental release have occasionally inflicted serious environmental damage ${ }^{1}$.

All petroleum products are derived from crude oil whose major constituents are hydrocarbons ${ }^{2}$. Crude oil is composed of complex mixtures of paraffinic, alicyclic and aromatic hydrocarbons and a smaller proportion of non-hydrocarbon compounds such as naphthenic acids, phenols, thiol, heterocyclic nitrogen, sulphur compounds as well as metallo-prophyrins and asphaltenes ${ }^{3}$.

Many microbial species have been implicated in crude oil degradation leading to a successful bioremediation of contaminated environment. Improvement of microbial efficiency has been directed towards the utilization of microbial seeding as a means of controlling oil spills ${ }^{4}$. Typical bacterial groups already known for their capacity to degrade hydrocarbons include Pseudomonas, Marinobacter, Alcanivorax, Microbulbifer, Sphingomonas, Micrococcus, Cellulomonas, Dietzia, and Gordonia groups ${ }^{5}$. Molds belonging to the genera Aspergillus,
Penicillium, Fusarium, Amorphoteca, Neosartorya, Paecilomyces, Talaromyces, Graphium and the yeasts Candida, Yarrowia and Pichia have been implicated in hydrocarbon degradation ${ }^{6}$.

Three major factors affect the biodegradation of crude oil and these are chemical composition of the oil, dissolved oxygen content of water and nutrient availability for microorganisms ${ }^{7}$. The type and number of microbial species involved in degradation may influence the rate and extent of the process ${ }^{8}$.

Contamination of the environment with crude oil above critical land results in pollution. Major oil spills over the years include: Torrey Canyon (1967), Argo Merchant (1976), Amoco Cadiz (1978), and recently the Exxon Valdez (1989). Oil spill through warfare include the Gulf war (1991) in which an estimated 0.8 to 2 million metric tonnes of oil was released in the Persian Gulf ${ }^{9}$. The more recent BP oil spill in the Gulf of Mexico which flowed for three months in 2010 is the largest accidental marine oil spill in the history of the petroleum industry. The spill has caused extensive damage to marine and wildlife habitats as well as the Gulf's fishing and tourism industries ${ }^{10}$.

Contamination of soil and groundwater with oil hydrocarbons is a global concern, especially in country as densely populated as Bangladesh because of their toxicity and recalcitrant properties ${ }^{11-}$

13. Ship breaking yards offer itself as the major source of petroleum 
hydrocarbon pollution and are rapidly growing in Bangladesh especially in the coastal area of Chittagong, the port city of Bangladesh. Most of the petroleum goes to the ecosystem via leak of costal oil refineries and ship breaking industries in Bangladesh. Considering the extent of pollution this research work was aimed at isolating the hydrocarbon degrading microorganisms present in the samples collected from shipbreaking yards and evaluating their petroleum hydrocarbon degrading properties.

\section{Materials and Methods}

\section{Sampling site and collection of samples}

Twenty different petroleum hydrocarbon contaminated composite samples (soil, water and combinations of soil and water) were aseptically collected from these ship scrapping areas. The $\mathrm{pH}$, temperature and colour of the samples were recorded. Sterile glass bottle, conical flasks, polythene bags, cottons, forceps and alcohol were used in collecting the samples and after that these were transported and stored at $4^{\circ} \mathrm{C}$.

\section{Enumeration of microorganisms}

Total bacterial count of the samples was determined by serial dilution followed by pour plate and spread method using nutrient agar as a medium.

\section{Selection of the isolates}

From a total of 20 samples, 35 colonies were isolated and finally 10 isolates were selected on the basis of their growth in Bushnell-

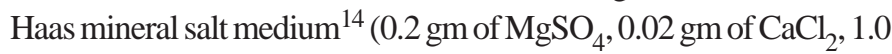
gm of $\mathrm{KH}_{2} \mathrm{PO}_{4}, 1.0$ gm of $\mathrm{K}_{2} \mathrm{HPO}_{4}, 1.0$ gm of $\mathrm{NH}_{4} \mathrm{NO}_{3}, 2$ drops of conc. Sol. $\mathrm{FeCl}_{3}$ in $1000 \mathrm{ml}$ of distilled water) supplemented with petroleum hydrocarbon such as kerosene, diesel and engine oil.

\section{Characterization and identification of the selected isolates}

The isolates were characterized and identified on the basis of their morphological, cultural, physiological and biochemical characteristics.

Determination of petroleum hydrocarbon degradation using greasy spot test

To perform this test, a brown paper bag or normal paper was cut into some $40 \times 40 \mathrm{~cm}$ square sheets. Then, with a ruler and pencil, the large square was divided into $4 \times 4 \mathrm{~cm}$ squares. Each square was designated by the code of the isolates and one was for control. Three drops from each treatment were deposited on the corresponding marked square. Then the circumference of each greasy spot was circled with a pencil and the diameter of each spot was measured and compared with the control.

\section{Estimation of petroleum hydrocarbon degradation}

Seven different isolates which showed comparatively good degradation capacity in greasy spot test were cultured in three sets of $150 \mathrm{ml}$ conical flask containing $25 \mathrm{ml}$ of mineral salt medium ${ }^{15}\left(0.5 \mathrm{gm} / \mathrm{L}\right.$ of $\mathrm{NH}_{4} \mathrm{Cl}, 0.5 \mathrm{gm} / \mathrm{L}$ of $\mathrm{K}_{2} \mathrm{HPO}_{4}, 0.5 \mathrm{gm} / \mathrm{L}$ of $\mathrm{NaH}_{2} \mathrm{PO}_{4}, 750 \mathrm{ml}$ of natural sea water, $250 \mathrm{ml}$ of distilled water, $\mathrm{pH}$
7.5). The first and second sets of conical flasks were supplemented with $0.2 \%$ of kerosene and diesel, respectively, while the third set was supplemented with $0.16 \%$ of engine oil ${ }^{15}$. Each flask was covered by aluminum foil. The cultures were maintained in shaker at $150 \mathrm{rpm}$ for 7 days at $30^{\circ} \mathrm{C}$. After 7 days of incubation cell free culture broth was extracted with three volumes $(75 \mathrm{ml})$ of toluene and extract was made up to $10 \mathrm{ml}$ and the OD (optical density) was measured at $420 \mathrm{~nm}$. The percentage of degradation was calculated from standard value ${ }^{16}$.

\section{Results and Discussion}

The temperatures, $\mathrm{pH}$ and no. of microorganisms of each sample are given in Table 1 . The total bacterial densities ranged from 2.7 $\mathrm{x} 10^{3}$ to $1.77 \times 10^{7} \mathrm{cfu} / \mathrm{gm}$ of sample. Ten bacterial isolates were finally selected on the basis of their growth on Bushnell-Hass mineral salt medium supplemented with kerosene, diesel and engine oil (Table 2) and identified on the basis of their morphological, cultural, physiological and biochemical characteristics. The bacterial isolates were provisionally identified as Listeria monocytogenes (F.S1c), Staphylococcus aureus (F.S2a), Pseudomonas alcaligenes (F.S3b), Listeria grayi (F.S6b), Bacillus pasteurii (F.S13a), Bacillus badius (F.S14b), Bacillus cirroflagellosus (F.S17a), Bacillus circulans (F.S17b), Bacillus brevis (F.S18b) and Citrobacter freundii (F.S19a).

Table 1. Temperature, $\mathrm{pH}$ and microbial load of the composite samples at the time of collection

\begin{tabular}{lccc}
\hline $\begin{array}{l}\text { No. of samples } \\
\text { \& types }\end{array}$ & $\mathrm{pH}$ & Temperature ${ }^{\circ} \mathrm{C}$ & $\begin{array}{c}\text { Total bacterial } \\
\text { count } \\
\text { (cfu/gm or ml) }\end{array}$ \\
\hline 1(Soil) & 5.24 & 27 & $4.95 \times 10^{5} / \mathrm{gm}$ \\
2(Soil) & 5.53 & 26 & $1.63 \times 10^{5} / \mathrm{gm}$ \\
3 (Soil) & 4.2 & 30 & $1.77 \times 10^{7} / \mathrm{gm}$ \\
4 (Water) & 3.9 & 32 & $1.47 \times 10^{6} / \mathrm{ml}$ \\
5 (Soil) & 6.2 & 29 & $2.6 \times 10^{5} / \mathrm{gm}$ \\
6(Soil) & 7.2 & 29 & $3.5 \times 10^{3} / \mathrm{gm}$ \\
7(Soil) & 7.1 & 30 & $4.1 \times 10^{3} / \mathrm{gm}$ \\
8(Soil) & 7.3 & 30 & $2.6 \times 10^{5} / \mathrm{gm}$ \\
9 (Water + Soil) & 6.4 & 30 & $5.16 \times 10^{3} / \mathrm{gm}$ \\
10 (Soil) & 8.7 & 32 & $2.7 \times 10^{3} / \mathrm{gm}$ \\
11 (Soil) & 7.4 & 31 & $2.6 \times 10^{5} / \mathrm{gm}$ \\
12 (Water + Soil) & 6.5 & 30 & $2.7 \times 10^{4} / \mathrm{gm}$ \\
13 (Soil) & 7.6 & 31 & $4.6 \times 10^{4} / \mathrm{gm}$ \\
14 (Soil) & 6.8 & 31 & $2.3 \times 10^{4} / \mathrm{gm}$ \\
15 (Water) & 6.5 & 29 & $2.7 \times 10^{4} / \mathrm{ml}$ \\
16 (Soil) & 7.1 & 31 & $3.24 \times 10^{5} / \mathrm{gm}$ \\
17 (Soil) & 7.3 & 29 & $4.2 \times 10^{5} / \mathrm{gm}$ \\
18 (Soil) & 6.8 & 32 & $1.65 \times 10^{6} / \mathrm{gm}$ \\
19 (Soil) & 6.5 & 30 & $2.6 \times 10^{5} / \mathrm{gm}$ \\
20(Soil) & 6.4 & 31 & $1.5 \times 10^{6} / \mathrm{gm}$ \\
\hline
\end{tabular}


Ahamed et al.

Table 2. Growth of different isolates in Bushnell-Haas mineral salt medium supplemented with $0.5 \%$ kerosene, diesel and engine oil

\begin{tabular}{lcccc}
\hline No. of isolate & Dextrose & Kerosene & Diesel & Engine oil \\
\hline F.S1c & ++++ & ++ & ++++ & ++ \\
F.S2a & ++++ & +++ & +++ & +++ \\
F.S3b & ++ & ++ & ++++ & ++++ \\
F.S6b & ++ & ++ & ++ & ++ \\
F.S13a & +++ & ++ & ++ & ++ \\
F.S14b & +++ & +++ & ++ & + \\
F.S17a & ++ & ++ & ++ & + \\
F.S17b & ++++ & +++ & ++++ & +++ \\
F.S18b & ++ & +++ & ++++ & +++ \\
F.S19a & +++ & ++ & +++ & + \\
\hline
\end{tabular}

'+' slight growth;

'++' moderate growth;

' +++ ' good growth;

'++++' excellent growth.

\section{Greasy spot test}

The greasy spot test was carried out to find out whether the isolates could break down the supplied petroleum hydrocarbon and if they do; to what extent they have the ability to perform their activities. After 10 days of incubation the highest (more than $50 \%$ ) degradation was shown by the isolate F.S3b ( $P$. alcaligenes) while after 15 days of incubation the diameter of the oil spots decreased by almost $65-75 \%$. After 20 days of incubation the highest (80\%) degradation of diesel had been shown by the isolate F.S1c (L. monocytogenes) (Table 3).

Table 3. Diameter (in cm) of oil spots after 20 days of incubation (Bushnell-Hass mineral salt medium supplemented with kerosene, diesel and engine oil)

\begin{tabular}{lccc}
\hline Isolate no. & \multicolumn{3}{c}{ Diameter of the oil spot (in cm) } \\
\cline { 2 - 4 } & Kerosene & Diesel & Engine Oil \\
\hline F.S1c & 0.4 & 0.3 & 0.8 \\
F.S2a & 0.6 & 0.4 & 0.5 \\
F.S3b & 0.4 & 0.4 & 0.5 \\
F.S6b & 0.4 & 0.5 & 0.7 \\
F.S13a & 0.6 & 0.6 & 0.8 \\
F.S14b & 0.6 & 0.6 & 0.7 \\
F.S17a & 0.5 & 0.7 & 0.6 \\
F.S17b & 0.7 & 0.8 & 0.4 \\
F.S18b & 0.5 & 0.4 & 0.5 \\
F.S19a & 0.5 & 0.4 & 0.7 \\
Control & 1.3 & 1.6 & 1.8 \\
\hline
\end{tabular}

\section{Estimation of petroleum hydrocarbon degradation}

Almost all the isolates showed $50 \%$ or more degradation of kerosene except F.S19a (C. freundii) which showed only $14.13 \%$ degradation. The top three kerosene degraders were F.S2a (S. aureus), F.S3b (P. alcaligenes) and F.S18b (B. brevis) which showed $78.26 \%, 76.08 \%$ and $73.91 \%$ degradation, respectively. Isolates F.S1c (L. monocytogenes), F.S14b (B. badius) and F.S17a (B. cirroflagellosus) degraded almost half of the supplied kerosene (Figure 1).

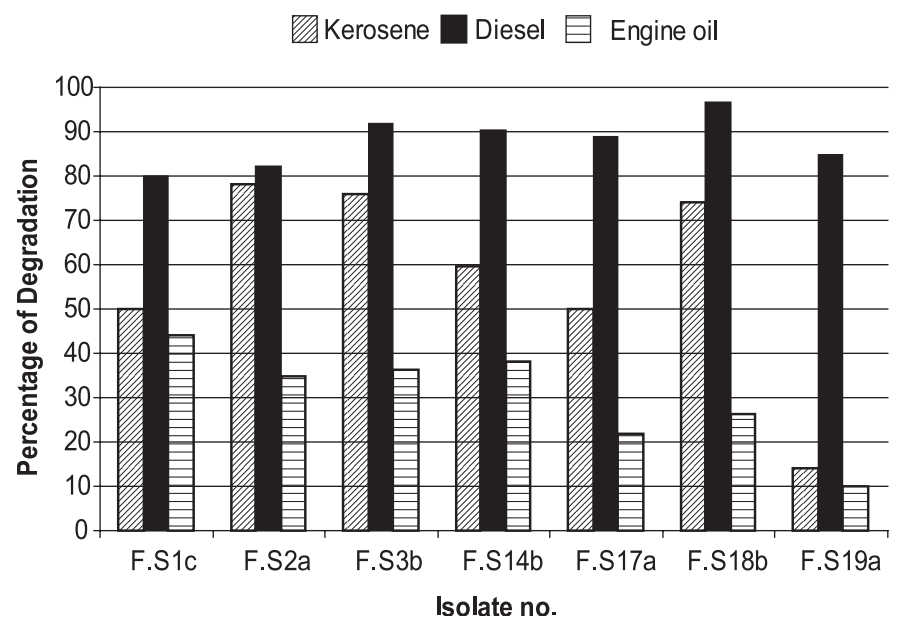

Figure 1. Degradation (\%) of kerosene, diesel and engine oil by different isolates after 7 days of incubation.

Diesel was found to be degraded maximum (96.8\%) by the isolates among the tested hydrocarbons. The highest $96.8 \%$ degradation of diesel was shown by F.S18b (B. brevis), followed by $92 \%$, $88.8 \%$ and $84.8 \%$ diesel degradation by the strains F.S3b ( $P$. alcaligenes), F.S17a (B. cirroflagellosus) and F.S19a (C. freundii), respectively (Figure 1).

Engine oil was the less degradable hydrocarbon used in the experiment (less then $50 \%$ degradation occurred by the selected strains). Isolates F.S1c (L. monocytogenes), F.S14b (B. badius) and F.S3b (P. alcaligenes) were found to be the top most engine oil degraders and these isolates degraded $43.97 \%, 38.29 \%$ and 36.17\%, respectively. The strain F.S19a (C. freundii) exhibited lowest engine oil degradation capacity (Figure 1).

When natural environments are contaminated with pollutants, the indigenous microbial communities are likely to contain microbial populations of different taxonomic characteristics, which are capable of degrading the contaminating chemicals ${ }^{17}$. Prior the screening of hydrocarbon degrading microorganisms, the bacterial populations were estimated in each original sample. Appreciable number of bacteria up to $10^{7} \mathrm{cfu} / \mathrm{gm}$ has been found to exist in the samples. Of the 10 bacterial isolates, 5 were found to be the member of the genus Bacillus sp. The discovery of P. alcaligenes was not surprising based on their frequency in the soil as well as their frequent biodegrading ability. Nevertheless, isolation and apparently a good growth of $S$. aureus on hydrocarbon substrates 
was surprising information. This bacterium has not been considered to be a strong hydrocarbon degrader previously.

The test to estimate the percentage of petroleum hydrocarbon degradation demonstrated a very good biodegrading capability of petroleum hydrocarbon by the present bacterial isolates. Thavasi et al. ${ }^{18}$ evaluated the biodegradation potential of four species of hydrocarbonoclastic bacteria (Bacillus megaterium, Corynebacterium kutscheri, Lactobacillus delbrueckii and Pseudomonas aeruginosa), using the same method mentioned earlier. The biodegradation results obtained by them inferred that, P. aeruginosa showed $85.15 \%$ crude oil degradation, followed by B. megaterium (78.5\%), C. kutscheri (76.4\%) and L. delbrueckii (71.6\%).

From the above mentioned characteristics, the isolates were seemed to be the effective petroleum hydrocarbon biodegraders. Further works on their enzymes and plasmids will allow discovering the mystery of these natural petroleum pollutant sweepers.

\section{Acknowledgements}

The authors are thankful to "Ministry of Science and Information \& Communication Technology”, Bangladesh for financial assistance under the project "Microbial Degradation of Petroleum Hydrocarbon” in the fiscal year 2008-2009.

\section{References}

1. Atlas RM and Bartha R. 1998. Microbial ecology: Fundamentals and Applications, $4^{\text {th }}$ edn, pp 511-530. Benjamin/Cummings Publishing Company, Inc. California, USA.

2. Karlsen DA and Larter SR. 1991. Analysis of petroleum fractions by TLC-FID: applications to petroleum reservoir description. Org Geochem. 17: 603-617.

3. Chapelle FH. 1993. Ground Water Microbiology and Geochemistry, $1^{\text {st }}$ edn, pp 573. John Wiley and Sons Inc., New York.

4. Odu CTI. 1972. Microbiology of soil contaminated with petroleum hydrocarbons. The extent of contamination of some soils and microbial properties after contamination. J Inst Petrol. 58: 201-208.
5. Brito EMS, Guyoneaud R, Goñi-Urriza M, Ranchou-Peyruse A, Verbaere A, Crapez MAC, Wasserman JCA and Duran R. 2006. Characterization of hydrocarbonoclastic bacterial communities from mangrove sediments in Guanabara Bay, Brazil. Research in Microbiology. In press.

6. Chaillana F, Flècheb A, Burya E, Phantavonga Y-hui, Saliot A and Oudot J. 2004. Identification and biodegradation potential of tropical aerobic hydrocarbon-degrading microorganisms. Res Microb. 155(7): 587-595.

7. Zhao J and Zhu J. 1997. Study on the biodegradation of oil spilled on the sea, pp 989-990. Proceedings of the $15^{\text {th }}$ International Oil Spill Conference, American Petroleum Institute, Washington DC, USA, 7$10^{\text {th }}$ April, 1997.

8. Walker JD and Colwell RR. 1975. Some effects of petroleum on estruarine and marine organisms. Canadian J Microbiol. 21: 305313.

9. Zhao J and Zhu J. 1993. Biodegradation of crude oil compounds, pp 431-438. Proceedings of the $13^{\text {th }}$ International Oil Spill Conference, Tampa, Florida, USA, 29 $9^{\text {th }}$ March- $1^{\text {st }}$ April, 1993.

10. Wikipedia. 2010. Deepwater Horizon oil spill. Available at: http:// en.wikipedia.org/wiki/Deepwater_Horizon_oil_spill. Accessed October 02, 2010.

11. Vidali M. 2001. Bioremediation. An overview. Pure Appl Chem. 73: 71163-71172.

12. Nisha S and Meera V. 2005. Bioremediation of phenol contaminated soil. Poll Res. 24: 481-485.

13. Hashibulla M. 2008. Isolation and characterization of hydrocarbon degrading microorganisms. M S Thesis, Dept. of Microbiology, CU.

14. Bushnell LD and Haas HF. 1941. The utilization of certain hydrocarbons by microorganisms. J Bacteriol 41: 653-673.

15. Juwarkar A and Khirsagar DG. 1991. Emulsification and oil degradation by marine bacteria. Indian J Mar Sci. 20: 78-79.

16. Rahaman KSM, Banal IM, Tahira J, Thayumanavan $\mathrm{T}$ and Laksmanaperumalsamy P. 2002. Bioremediation of gasoline contaminated soil by a bacterial consortium amended with poultry liter, coir pith and rhamnolipids biosurfactant. Bioresour Technol. 81: 25-32.

17. Bartha R and Atlas RM. 1977. The microbiology of aquatic oil spills. Adv Appl Microb. 22: 225-266.

18. Thavasi R, Jayalakshmi S, Radhakrishnan R and Balasubramanian T. 2007. Plasmid Incidence in Four Species of Hydrocarbonoclastic Bacteria Isolated from Oil Polluted Marine Environment. Biotechnol. 6(3): 349-352. 